mixtures of cyclohexane, benzene, tetrahydrofuran, acetone and methanol at $35^{\circ} \mathrm{C}$ and cyclooctane, $p$-xylene, mesityl oxide and $n$-butanol at $90^{\circ} \mathrm{C}$, respectively.

The results indicated that the mixed phases by both method A and B had nearly same characteristics and the polarity of the mixed phases changed in parailel with the composition of stationary liquids. The addition of a small amount of the polar stationary liquids $(2.5 \%)$ to $20 \%$ nonpolar phases caused an effective depression of tailing of oxygen-containing materials in either method $\mathrm{A}$ or $\mathrm{B}$.

(Received May 24, 1962)

\title{
ジエチルジチオカルバミン酸ナトリウムを 用いた銅の交換抽出ポーラログラフィー*
}

\author{
藤永 太一郎, 石橋 道弘, 山下 和男**
}

\begin{abstract}
キレート剤として，ジエチルジチオカルバミン酸ナトリウム（以後 Na-DDTC と略記）在用い，金 属キレートの相互交換反応を利用した溶媒抽出分離ポーラログラフィーてついて，藷者らはすこにタり

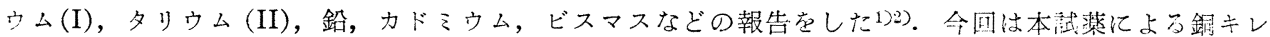

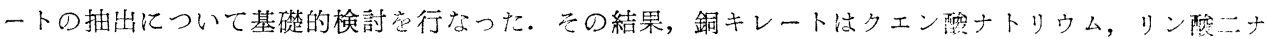

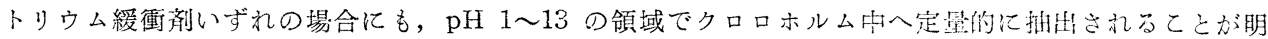
らかになった。との際，緩衝剤グリシン pH 9〜13 の領域で，シアン化力リウムのマスキング効果を 調べた。銅结完全にマスクされ，その抽出率は0\%に下るが，EDTA 注 pH 1〜13 域で，銅に対して なんらマスキング效果を示さないてとがわかった。クロロホルム中に抽出き䊽た跲キレ一トから銅在水

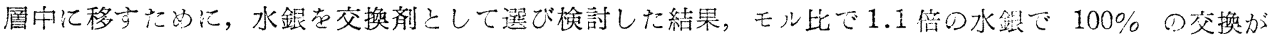
扣てって放り，この際の過剩の水銀は $1 N$ 硫酸酸性で硫酸ヒドラジンを作用させて金属に還元し，口 過除去することによって銅の定量は可能となった。 ビスマスと銅の波の分䧴にはクエン酸ナトリウム

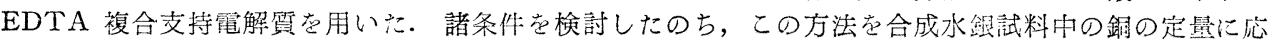
用し， $0.005 \%$ の銅を 土4\%の誤差で定量できた。
\end{abstract}

\section{1 緒言}

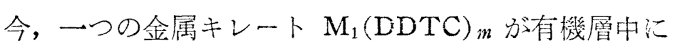
存在するとき，これより更に安定なキレートを形成する 他金属イオン $\mathrm{M}_{2}{ }^{n+}$ を加えると, 次式に示すような交換 反応がおこる。

$$
\begin{aligned}
& n\left[\mathrm{M}_{1}(\mathrm{DDTC})_{m}\right]_{\mathrm{org}}+m\left[\mathrm{M}_{2}{ }^{n+}\right]_{\mathrm{aqu}} \\
& \quad \rightleftarrows n\left[\mathrm{M}_{1}^{i n+}\right]_{\mathrm{aqu}}+m\left[\mathrm{M}_{2}(\mathrm{DDTC})_{n}\right]_{\mathrm{org}}
\end{aligned}
$$

各種の金属イオンのつくる DDTC キレートにおけ

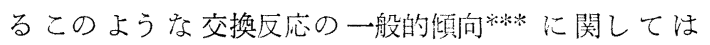
Bode $^{3) \sim 7)}$, Eckert ${ }^{3)}$ らによって経験的にその系列が示 されている. 上式に示すような交換抽出吂利用して微量

* ポーラログラフによる分析化学的研究（第 42 報）

** 京都大学理学部化学教室 : 京都市左京区吉日本町

$$
\text { *** } \begin{aligned}
\mathrm{Hg}>\mathrm{Ag} & >\mathrm{Cu}>\mathrm{Ni}>\mathrm{Bb}>\mathrm{Cd}>\mathrm{Sn}^{3+}, \\
\mathrm{Fe}^{3+}>\mathrm{As}^{3+}, \mathrm{Zn}>\mathrm{Mn} &
\end{aligned}
$$

分析を行なう場合，此色法を速用しようと少礼ば，金属 イオンあるいはキレートが呈色していなけ礼ばならず，

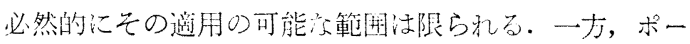
ラログラフ法によれば，支持電膘質の嘚当な選択によっ て，そのような制腿を受けることは少ない出，乙かし， 測定のために有機層から再び水層へ目的成分を移さ社壮 ならないという点において，迅速性を欠くという久点が ある. 彷来, このような交換反忘索利用して, 有機層中 の微量の銅を比色法によって定量しょうとした研究はい くつか知られている9 11). しかし，有機履中の銅を水 層中に交換反応を利用して移し，定量した例法知られて いない，著者らはまず直流ボーラログラフを用い，銅一 DDTC キレートの抽出について消条件を检村した結果，

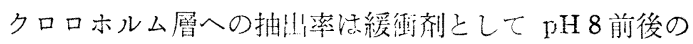
グリシンを使用した場合，やき佂下与る以外はすべての $\mathrm{pH}$ 領域（1〜13）に拉いて定量的に抽出されることが明 らかになった，次にクロロホルム層に抽㤝された銅一 
DDTC キレートに対して，交換剂に水銀 (II) の水溶液 を用いると，水銀がモル比で銅の 1.1 倍以上存在古れば 銅は $100 \%$ 水曆中にもどる.ただ $\mathrm{pH}$ が 1 以下になると 交換速度が遅くなる現象がみられた。この操作におい て，水層中に残る過剩の水銀はポーラログラフ的に銅よ り前放電であるから，水銀が $1 \times 10^{-4} M$ 共存していると き $1 \times 10^{-4} M$ 以下の銅の定量は困難になる．この際，硫 酸ヒドラジンを $1 N$ 硫酸酸性で作用させ水銀を金属に還 元しておけば，その妨害は除去でき， $1 \times 10^{-5} M$ の銅が 定量可能となることがわかった．本法において妨害元素 としては水銀，ビスマスが考えられるが，水銀は分別抽 出によって除くことが可能であり，ビスマスはクエン酸 ナトリウム EDTA 複合支持電解質12)を用いることによ ってその妨害它除くことができる.よって，この方法を 水銀中の微量の銅の定量に適用し，約 $0.005 \%$ の銅を誤 差 $\pm 4 \%$ で定量できることを見いだした．以下，その詳 細について述べる.

\section{2 試薬と装置}

\section{$2 \cdot 1$ 試 薬}

(1) DDTC 液：特級 Na-DDTC を $0.1 N$ 水酸化 カリウムまたは $0.1 N$ アンモニア水に溶解し, $0.5 \%(\mathrm{w} /$ v）浴液として貯蔵した。

（2）クロロホルム：分液ロート中に打いて濃硫酸で 着色しなくなるまで洗い，アルコールなどを除き，水酸 化ナトリウムの希溶液とふり, 最後に冷水で十分洗浄乾 燥したのち精留して用いた。

（3）銅 (II) 溶液：金属銅 $(99.95 \%)$ を $0.3204 \mathrm{~g} ひ$ 上う取して濃硝酸 $5 \mathrm{~m} l$ 亿溶解し，てれを純水で $500 \mathrm{ml}$ そ希橎して $1.084 \times 10^{-2} M$ 溶液とした。

（4）水銀 (II) 溶液：特級硝酸第二水銀苍用い，1.0 $\times 10^{-2} M$ にしてかっ色でん中に保存した. 力洒は常法 飞従って硫酸第二鉄アンモ二ウムを指示薬として，チ才 シアン酸アンモニウム標準液で滴定するととによって決 定した. また， $3 \cdot 2 \cdot 2$ で用いた水銀(II) は精製純金属水 銀を硝酸に溶解して用いた。

（5）その他：クエン酸ナトリウム，グリシン溶液は それぞれ $1 M$ 溶液とし, リン酸二ナトリウム溶液は 0.5 $M$ として貯蔵した. すべて特級品を用い, その他過塩素 酸，硝酸，アンモニア水などは，いずれも特級品または 再蒸留を行なった純品である。

\section{$2 \cdot 2$ 装 踶}

（1）ポーラログラフ：柳本製作所製ペン記録式ガル バレコーダー.

水銀滴下電極： $1 N$ 硫酸酸性，加電圧 $0 \mathrm{~V}$ (開回路) そて $m=0.66 \mathrm{mg} / \mathrm{sec}, t=4.2 \mathrm{sec}$.

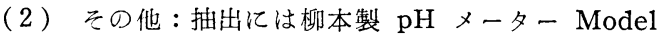
42-A，イワキ社製シェーカーなどを使用した。

\section{3 実験および結果}

\section{$3 \cdot 1$ 基礎条件の検討}

$3 \cdot 1 \cdot 1$ 銅-DDTC 錯体の抽出率曲線 $10^{-3} M$ 銅 (II) 溶液 $2 \mathrm{ml}$, 緩衝版溶液（1Mグリシン, クエン酸ナトリ ウム，リン酸二ナトリウムなど）を $5 \mathrm{ml}$ または $10 \mathrm{ml}$, $0.5 \%$ DDTC 溶液 $5 \mathrm{~m} l$, 純水 $90 \mathrm{~m} l$ を加えたのち, 水 酸化カリウムまたはアンモニア水, 硝酸で $\mathrm{pH}$ を調節 し, 5 分間放置したのち, $300 \mathrm{ml}$ 容分液ロートに移す. 20, 20, $10 \mathrm{ml}$ のクロロホルムでおのおの 5 分間ふって 15分間静置したのち, 全クロロホルム層を $100 \mathrm{ml}$ ビーカ 一中に移す.このクロロホルム層内の銅(II) を定量する ため, 混酸(過塭素酸 : 硝酸 $=3: 1$ ) $8 \mathrm{ml}$ を加えてよく 混ぜ，加熱によりクロロホルムをとばすとともにキレー 卜を分解する. 分解後残液 (約 $2 \mathrm{~m} l$ ) を $20 \mathrm{~m} l$ ×スフラ スコに移し，水で標線まで満たしてよく振り, 10 分間案 素ガス通気後， $-0.1 〜-0.6 \mathrm{~V}$ 対水銀池で直流ポーラロ グラムをとる. 回収率は破壊操作の前に $10^{-3} M$ 銅 (II) 溶液をさらに $2 \mathrm{~m} l$ 加えて上記と同様に操作し, 波高を 比較して求めた。 その結果は Fig. 1 に示した。 寸なわ ち，緩衝剤がグリシンの場合， $\mathrm{pH} 8$ に括いて抽出率が 下る以外は全 $\mathrm{pH}$ 域において銅はクロロホルム層へ定量 的に抽出される. グリシン $\mathrm{pH} 8$ の場合でも, EDTA を加えれば 100\% 抽出される.この現象の理由について はまだ明らかにされていない。

\section{3・1.2 EDTA およびシアン化カリウムのマスキング} 効果 EDTA とシアン化カリウムについて銅に対す るマスキング効果を検討するため，3・1・1 と同操作によ って抽出率を測定した. EDTA $0.02 M$, シアン化力 リウムは $0.1 M$ とした. シアン化カリウムについては pH 9〜13 域で検討したが，銅は完全にマスクされ抽出 率は 0\%であった。他方, EDTA の存在下では定量的 に抽出された。 EDTA は他の元素に対しては有効なマ スキング効果を示すことが報告されているので，銅の抽 出に対して，これを用いることは有効であり，反対に銅 の抽出を望まないときはシアン化カリウムを用いればよ w.

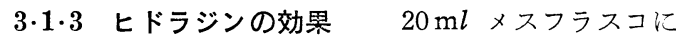
$10^{-3} M$ 銅 (II) 溶液 $2 \mathrm{ml}, 10^{-2} M$ 水銀 (II) 溶液 $1 \mathrm{~m} l$, $0.2 \%$ ポリアクリル・アミド（P.A.A.） $1 \mathrm{ml}, 10 \mathrm{~N}$ 硫酸 $2 \mathrm{~m} l$ を順次加え, これに $0.1 M$ 硫酸ヒドラジン溶 液を $0.1 ， 0.2 ， 0.5,2 ， 5,10 \mathrm{ml}$ と加え，それぞれよ くふったのち沈殿をロ過除去する. 口液を直流ポーラロ グラフにとる. Fig. 3 にみられるように， $0.1 M$ ヒド ラジン溶液を $2 \mathrm{~m} l$ 加えると, 十分水銀を除去すること 


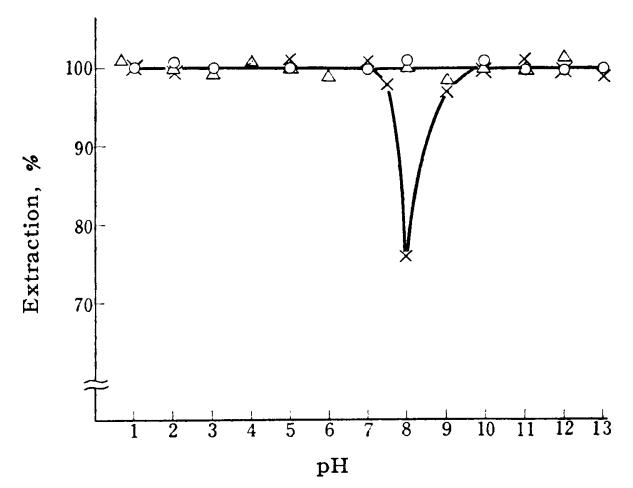

Fig. 1 Extractability of copper(II) by $\mathrm{Na}$ DDTC in the presence of Na-citrate, $\mathrm{Na}$-phosphate or glycine, as influenced by $\mathrm{pH}$, and in the absense of EDTA -O- Na-citrate $-\triangle-$ Na-phosphate $-x-$ Glycine

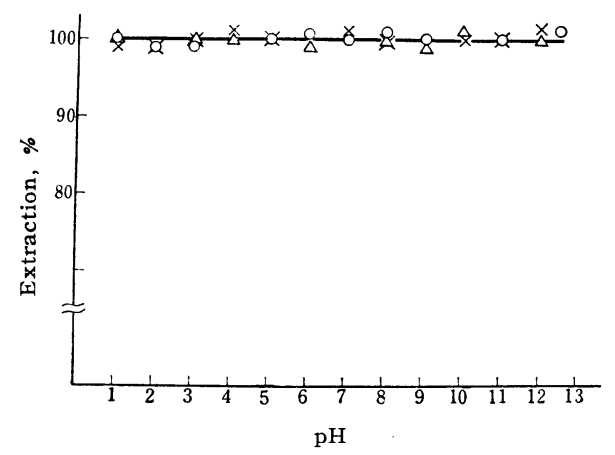

Fig. 2 Extractability of copper(II) by $\mathrm{Na}$ DDTC from the solution containing $0.2 M$ EDTA $10 \mathrm{~m} l$ in $100 \mathrm{~m} l$ in the presence of Na-citrate (-O-), Naphosphate $(-\triangle-)$ or Glycine $(-\times-)$

ができ，直流ポーラロログラフによって銅の定量が可能 であることがわかった。 なお， $5,10 \mathrm{ml}$ では大過剩に なっているが，そのために波形，波高の異常，増減は見 られなかった. $0.1 M$ ヒドラジン溶液 $2 \mathrm{ml}$ は固体の硫 酸ヒドラジン約 $26.0 \mathrm{mg}$ に相当するので, 以後注固体 $50 \mathrm{mg}$ 索接加えた。

$3 \cdot \mathbf{3}$ EDTA 共存時のヒドラジンの還元効果 20 $\mathrm{m} l$ メスフラスコに $0.2 M$ EDTA を $0.5 \mathrm{~m} l$, あるい は $1 \mathrm{ml}$ 加え, ヒドラジンその他は $3 \cdot 1 \cdot 3$ と全く同一条 件で処理して直流ポーラログラフをとり，水銀の還元に およぼす影響を検討した。その結果，水銀波は減少しな いことがわかった，従って，ヒドラジンではもはや金属

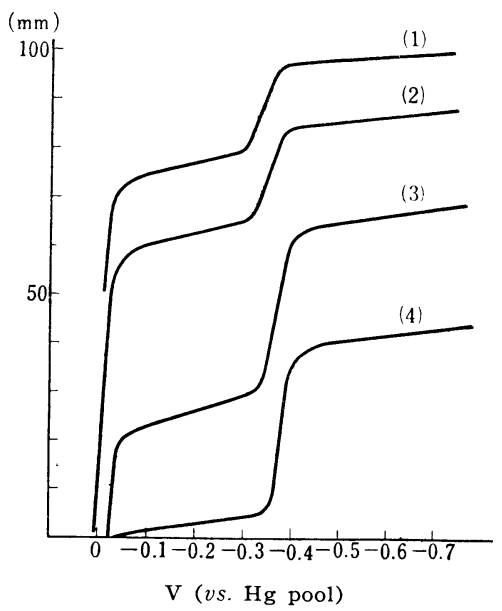

Fig. 3 The reduction effect of hydrazine on mercury(II) in $1 \mathrm{~N} \mathrm{H}_{2} \mathrm{SO}_{4}$ solution

Curve (1) Addition of $2 \mathrm{ml} 10^{-2} M$ hydrazine sulfate solution

Curve (2) Addition of $5 \mathrm{ml} 10^{-2} M$ hydrazine sulfate solution

Curve (3) Addition of $1 \mathrm{ml} 10^{-1} M$ hydrazine sulfate solution

Curve (4) Addition of $50 \mathrm{mg}$ solid hydrazine sulfate

Sens : (1) (2) $0.02 \mu \mathrm{A} / \mathrm{mm}$, (3) (4) $0.01 \mu \mathrm{A} / \mathrm{mm}$

Table I Influence of hydrazine on the wave height of copper in $25 \mathrm{ml}$ solution containing $2 \mathrm{ml} \quad 10^{-3} M \mathrm{Cu}(\mathrm{II})$ and $2 \mathrm{~m} l 10 \mathrm{~N} \mathrm{H}_{2} \mathrm{SO}_{4}$

\begin{tabular}{cc}
\hline $\begin{array}{c}\text { Taken } \\
\text { hydrazine }(\mathrm{m} l)\end{array}$ & $\begin{array}{c}\text { Wave height }(\mathrm{mm}) \\
1 \mathrm{~mm}=0.004 \mu \mathrm{A}\end{array}$ \\
\hline 1 & 66 \\
2 & 65 \\
5 & 65 \\
10 & 65 \\
\hline
\end{tabular}

にまで還元することができなくなったものと思われる. このように EDTA の混在は還元除去に対して好ましく ないので, 抽出の際, マスキング剤として EDTA を用 いたときは，EDTA を含まない同組成液で 2 回以上洗 って，完全にその混入を防止しなければならない。

\section{1 .5 逆抽出水溶液種の検討 $10^{-3} M$ 銅(II) の 5} $\mathrm{m} l$ を含を（a） $0.05 M$ クエン酸ナトリウム緩衝溶液 $\mathrm{pH} 6$ について，3·1·1 の操作によって銅(II) をクロロ ホルム層に抽出し, 全クロロホルムと逆抽出溶液 $30 \mathrm{ml}$ $\left(10^{-2} M\right.$ 水銀(II) $1.5 \mathrm{ml}$ を含んだ $0.05 M$ クエン酸ナト リウム $\mathrm{pH} 6$ の水溶液）と 5 分間ふり, 15 分間静置し たのち, 約 $2 \mathrm{ml}$ の洗液とともに $50 \mathrm{ml}$ メスフラスコに 移し, $10 N$ 硫酸 $5 \mathrm{ml}, 0.2 \%$ P. A. A. $2.5 \mathrm{ml}$, 硫酸七 
ドラジン $50 \mathrm{mg}$ を㮌次加えてよくふり，過剩の水銀を 還元口過除去したのち口液をポーラロにとる. 他方, 有 機層は抽出率を求めた $3 \cdot 1 \cdot 1$ の破壊法によって交流ポー ラログラムをとり銅の残存の有無を確認した。同様な操 作を（b） $0.05 M$ クエン酸ナトリウム， $\mathrm{pH} \mathrm{11，(c)}$ $1 N$ 硫酸，（d） $0.05 M$ グリシン, $\mathrm{pH} 11$ の各溶液につ いても適用した。その絬果，(a), (b), (c), (d) いず れも有機層には銅 (II) の残存が認められなかった。 ま た，(c)の場合を除いて注 (a), (b)，(d)とも良好なポ 一ラログラムが得られ, 以後逆抽出相として, グリシン また汸クエン酸ナトリウムを用いた. ( c ) 法強酸性のた めに DDTC が分解し，その分解生成物が混入するため に良好なポーラログラムが得にくい，以後，pH 11 で 行なうようにした。

\subsection{6 逆抽出に要する水銀 $($ II $)$ の量 $3 \cdot 1.5$ の} ( a ), (b ), (d)の打の打のの場合の水銀(II)の量をモル 比で銅 (II) の 1.1 倍, 1.2 倍, 1.5 倍, 2 倍量逆抽出層 に含もようにして同様澡作し，交換に要する水銀 (II) 量を検討したところ，いずれの場合も 1.1 倍以上，すな わち，銅の当量以上で完全に交換していた，緩衝能が弱 くなるが，クエン酸ナトリウムについて $\mathrm{pH} 11$ でも検 討したのは，後述するようにビスマス (III) と銅(II)の 分離にそのまま支持電解質となりうるからである，銅の 回収率注逆抽出後, さらに水層に $10^{-3} M$ 銅(II) $5 \mathrm{ml}$ を 加えたものについてポーラログラムをとり，加えないも のの波高と比較して求めた.

\section{$3 \cdot 1 \cdot 7$ ヒドラジンの還元カにおよぼすクエン酸ナト} リウムの影響＼cjkstart本法に抢いては逆抽出層がそのままポ 一ラログラフへの供試液となるので, クエン酸ナトリウ ムを䌅衝郕と同時に支持電解質として用うべく，その濃 度の影響について考察した. $10^{-3} M$ 銅(II) $2 \mathrm{ml}, 10^{-3} M$ ビスマス (III) $2 \mathrm{~m} l, 10^{-1} M$ 水銀(II) $1 \mathrm{~m} l$ をそれぞれ $20 \mathrm{ml}$ ×スフラスコにとり, クエン酸ナトリウムの濃度 は $0,0.05,0.1 M \cdots \cdots$ と变光, 他の操作は $3 \cdot 1.3$ と同 様に行なって直流ポーラログラムをとった，その結果は Fig. 4 に示した. $0.1 M$ クエン酸ナトリウムでは水銀 (II) はヒドラシンによって定量的に還元されるが, $0.2 M$ ではやや残存する。この場合ビスマス (III) と銅 (II)の 波互いに重なっており，0.4M になるとヒドラジンの 還元力は著しく弱まるが，波注良好に分離される．従っ て,クエン酸ナトリウムの使用はビスマス(III) と銅(II) の同時定量に有効であるが， $0.3 M$ 以上ではヒドラジン の還元力を減退させるので, $3 \cdot 1.8$ と考え合せて $0.1 M$ 以下で，いったえ $1 N$ 硫酸酸性により水銀(II)をヒドラ ジンで還元除去してから，その口液の適当量をとり，

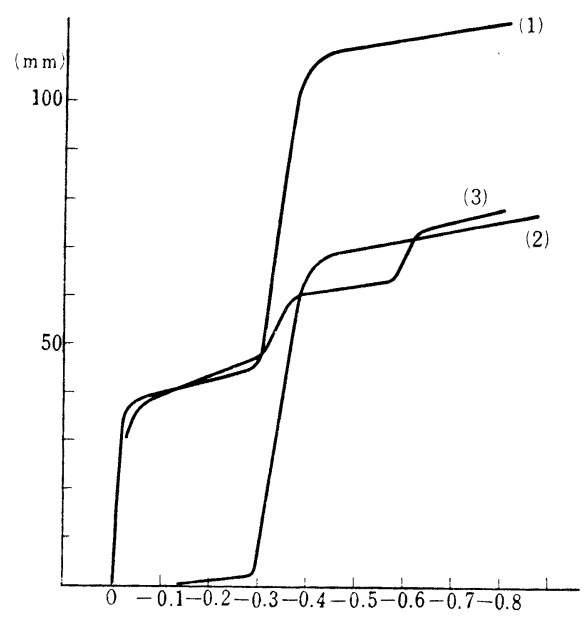

$\mathrm{V}$ (vs. $\mathrm{Hg}$ pool)

Fig. 4 Influence of $\mathrm{Na}$-citrate on the reduction effect of hydrazine

Curve (1) $0.1 M$ Na-citrate Curve (2) $0.2 M \mathrm{Na}$-citrate Curve (3) $0.4 M$ Na-citrate $20 \mathrm{ml}$ of each solution contained $1 \mathrm{ml} 10^{-2} M$ $\mathrm{Hg}(\mathrm{II}), 2 \mathrm{ml} 10^{-3} M \mathrm{Bi}(\mathrm{III}), 2 \mathrm{ml} 10^{-3} \mathrm{Cu}(\mathrm{II})$, $2 \mathrm{ml} 10 \mathrm{~N} \mathrm{H}_{2} \mathrm{SO}_{4}$ and $1 \mathrm{ml} 0.2 \%$ P. A. A. in $20 \mathrm{ml}$ solution

Sens : (1) (2) $0.01 \mu \mathrm{A} / \mathrm{mm}$, (3) $0.02 \mu \mathrm{A} / \mathrm{mm}$

$0.5 M$ クエン酸ナトリウムにしてやるとよい. この際, EDTA も $0.01 M$ にして複合支持電解質とすると, さ らに良好な分離波が得られるが，希釈されるので定量限 界は打ちる。

$3 \cdot 1 \cdot 8$ 波高におよぼす緩衝剤の影響 $\quad 3 \cdot 1.7$ と同 様の理由により各緩衝郕の濃度による波高への影響につ いて調べた. $10^{-3}$ 銅 (II) $2 \mathrm{~m} l, 0.2 \%$ P. A. A. $1 \mathrm{~m} l$ を $20 \mathrm{~m} l$ メスフラスコにとり,緩衝郕の濃度をそれぞれ， 0，0.05，0.1，0.2，0.3M 亿なるようにとり，それらを ポーラログラフにとった. それらの結果を Fig. 5 に示 した. $0.2 M$ 以下では各緩衝郕とも影響はなく，抽出抒 よび逆抽出層のそれらの濃度は $0.05 M$ としているので， なえら影響がないことがわかった。

3.1.9 妨害元素の検討 ポーラログラフ的化妨害 する元素として, 水銀(II)とビスマス(III)が考元られる が，これらはいずれも EDTAによってマスクされない が，水銀（II）注銅（II）ょりDDTC とはょり安定なキ レートを形成するので，試料に DDTC 溶液を少量ずつ 加え，分別抽出することによって，大部分除去すること ができる．最後に銅(II) に随伴して抽出された水銀 (II) は交換郕に水銀(II) 水溶液を用いたので, 有機層に残存 


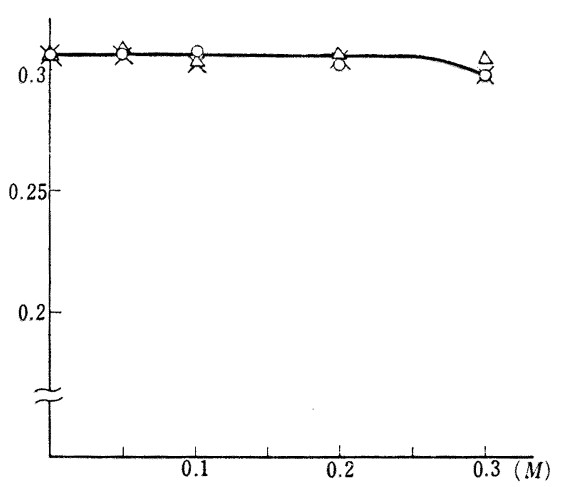

Fig. 5 Influence of the buffering agents on the wave of copper

-O- Na-citrate $-\triangle-$ Na-phosphate $-x-$ Glycine

$20 \mathrm{~m} l$ solution contained $2 \mathrm{~m} l 1 \times 10^{-3} M \mathrm{Cu}$ (II), $2 \mathrm{~m} l 10 \mathrm{~N} \mathrm{H}_{2} \mathrm{SO}_{4}$ and $1 \mathrm{~m} l 0.2 \%$ P. A. A.

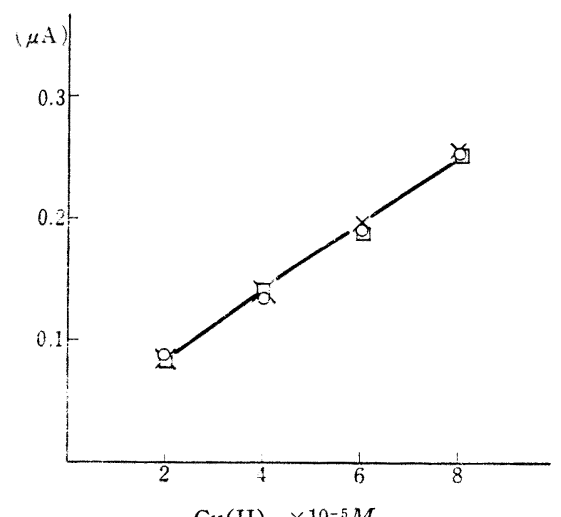

Fig. 6-a Calibration curve of copper(II) $20 \mathrm{~m} l$ of each solution contained ; $-\mathrm{O}-2 \mathrm{ml} 10^{-2} M \mathrm{Hg}$ (II) reduced with hydrazine, $-\times-$ no $\mathrm{Hg}$ (II), $1 \mathrm{ml} 1 M$ Na-citrate

Supporting electrolyte : $1 \mathrm{~N} \mathrm{H}_{2} \mathrm{SO}_{4}$ with $0.01 \%$ P. A. A.

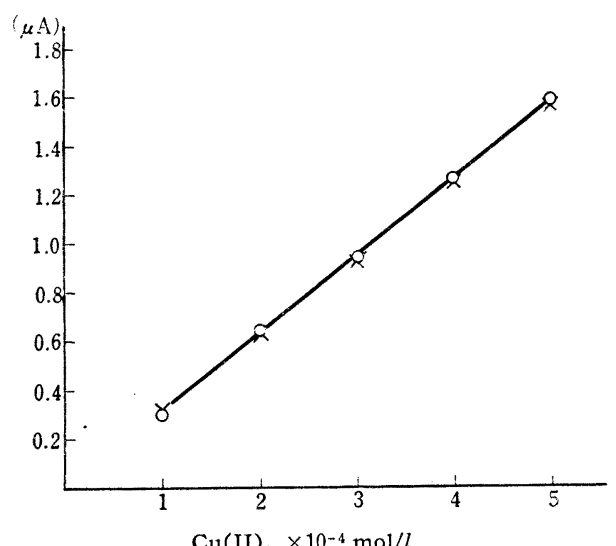

Fig. 6-b Calibration curve of copper(II)
し銅(II)のみが逆抽出される.交換剂の過剩の水銀 (II) は $3 \cdot 1 \cdot 3$ に述べた方法によって除くことができる.ビス マス (III) は $0.5 M$ クエン酸ナトリウムあるいは $0.5 M$ クエン酸ナトリウム $-0.01 M$ EDTA 複合支持電解質を 用いることによって，なえら銅の走量を妨害しない。

3.1.10 検量線の比較 $3 \cdot 1 \cdot 3$ あるいは $3 \cdot 1 \cdot 9$ によ る操作を行なった際の銅(II)の検量線と， $1 N$ 硫酸酸性， 0.01\% P. A. A.のみのそ机について比較してみた。 そ れぞれ良好な検量線を示し，相互によく一致して $1 \times$ $10^{-5} M$ 銅(II) まで比例性があった.

\section{$3 \cdot 2$ 定量法}

$3 \cdot 2 \cdot 1$ 推奖できる操作 試料は最終濃度が $1 \times 10^{-5}$ 〜 $8 \times 10^{-4} M$ 銅 (II) になるよう採取し，その溶液を緩衝 鼡クエン酸ナトリウム $0.05 M$ で $\mathrm{pH} 6$ になるように調 節し，マスキング剤として EDTA と用いるときはグリ シン（またはクエン酸ナトリウム） $0.05 M \mathrm{pH} 11$ にし て抽出抢よび逆抽出を行なう。操作法は四示した。

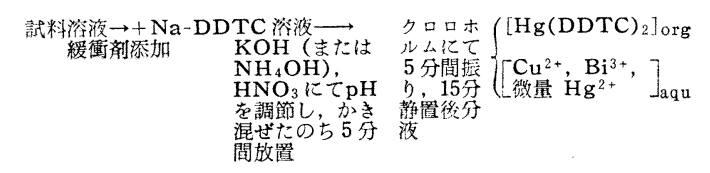

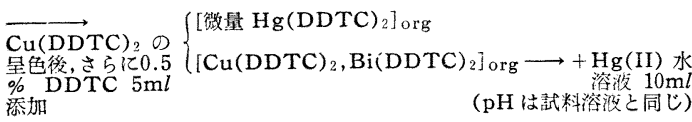

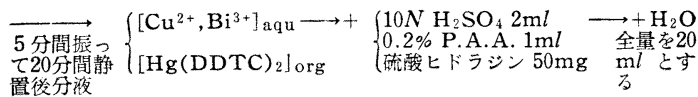

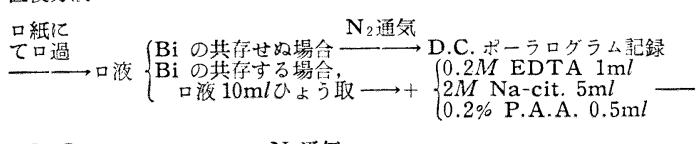
$\stackrel{+\mathrm{H}_{2} \mathrm{O}}{\longrightarrow}$ 全量 $20 \mathrm{~m} l$ とする $\stackrel{\mathrm{N}_{2} \text { 通気 }}{\longrightarrow}$ ポーラログラム乵録

Table II Determination of copper in mercury

\begin{tabular}{cccccc}
\hline $\mathrm{pH}$ & \multicolumn{3}{c}{ Sample taken } & $\begin{array}{c}\text { Cu found } \\
(\mu \mathrm{g})\end{array}$ & $\begin{array}{c}\text { Error } \\
(\%)\end{array}$ \\
\cline { 2 - 4 } & $\mathrm{Hg}(\mathrm{mg})$ & $\mathrm{Cu}(\mu \mathrm{g})$ & $\mathrm{Bi}(\mu \mathrm{g})$ & 311.3 & -2.4 \\
1.5 & 100 & 317.7 & 0 & 308.8 & -2.8 \\
1.1 & 100 & 317.7 & 0 & 61.13 & -3.8 \\
1.1 & 100 & 63.54 & 418 & 61.51 & -3.2 \\
1.5 & 100 & 63.54 & 418 & 30.60 & -3.7 \\
1.5 & 200 & 31.77 & 167.2 & 30.65 & -3.5 \\
1.5 & 300 & 31.77 & 0 & 15.24 & -4.0 \\
1.5 & 300 & 15.88 & 0 & & \\
\hline
\end{tabular}

$3 \cdot 2 \cdot 2$ 合成試料の分析 $3 \cdot 2 \cdot 1$ の方法を多量水銀 中の銅の定量に応用した. その結果は Table II に示し た. Table II から明らかなように, 約 $0.005 \%(\mathrm{w} / \mathrm{w})$ 
の水銀中の銅が誤差 $\pm 4 \%$ 以内で䇥量できた.

なお,水銀(II) は pH 2 あたりから沈殿するが,DDTC を加えると与べてクロロホルム中に抽出され,銅-DDTC キレートのクロロホルムへの抽出に対しては, 水銀 (II) の量が $100 \mathrm{mg}$ まではほとえど影響がみられなかった。

終りに，本研究に対して，終始御烈篤な御教示をいた だいた神可大学早川久婎博士に謝意を表します.

\section{文献}

1) 石穚道弘：本誌，11，426(1962).

2) 日本分析化学会第 10 年会 (東京); 日本化学会第 15 年会 (京都) 発表済.

3) H. Bođe : $Z$. anal. Chem., 142, 414 (1954).

4) H. Bode : ibid., 143, 182 (1954).

5) H. Bode : ibid., 144, 90 (1955).

6) U. Bode : ibid., 144, 165 (1955).

7) H. Bode : ibid., 157, 414 (1957).

8) G. Eckert : ibid., 155, 23 (1957).

9) M. Kovarik, V. Vins : ibid., 147, 401 (1957).

10) V. Sedinec, V. Vasak : Chem. Listy, 45, 435 (1951).

11) R. J. Martens, R. E. Githens, St. : Anal. Chem., 24, 991 (1952).

12) 石橋道弘, 永井外代士, 藤永太一郎, 舟阪 渡: 本誌, 8, 107 (1959).

13) K. Heller, G. Kuhla, F. Machek : Mikrochem., 11, 88 (1954); 17, 254 (1957).

Polarographic determination of copper(II) by means of diethyldithiocarbamate-chloroform extraction followed by back extraction with mercuric ion. (Studies on the polarographic analysis. XXXXII.) Taitiro FuJINAGA, Mitihiro
Isibasi and Kazuo Yamasita (Laboratory of Analytical Chemistry, Chemistry Institute,Faculty of Science, University of Kyoto)

The extraction of copper(II)-diethyldithiocarbamate(DDTC) into chloroform was examined in the presence of masking agents such as EDTA or potassium cyanide and of buffering agents such as sodium citrate, sodium phosphate and glycine; the chloroform extract was evaporated with small amounts of aqueous mineral acid and the resulting solution was examined polarographically after the addition of suitable supporting electrolyte.

It was found that copper could be extracted quantitatively from the solution of $\mathrm{pH}$ ranging from 1 to 13 even in the presence of EDTA, however it was not extracted by the method in the presence of potassium cyanide. The reextraction of copper from chloroform layer into aqueous solution with mercuric ion was also studied and the re-extraction was found quite qualitative when the amount of mercuric ion exceeded that of copper. As the results, it was found that $1 \times 10^{-5} \mathrm{~mole} / l$ copper could be conveniently separated, concentrated and determined polarographically; the excess mercuric ion could be removed by the reduction with hydrazine sulfate if necessary.

Bismuth did not disturb the determination of copper by the use of sodium citrate-EDTA mixture as the supporting electrolyte.

The method was successfully applied for the micro determination of copper in a large amount of mercury; $0.005 \%(\mathrm{w} / \mathrm{w})$ copper in mercury was determined within an error $\pm 4 \%$.

(Received July 9, 1962)

\title{
イオン交換法を用いるトリウム中の微量カドミウムの分離定量
}

\author{
平野 四蔵*, 水池 敦, 飯田 芳男**
}

\begin{abstract}
原子炉用トリウム化合物中の 極微量カドミウムをイオン交換分離ーポーラログラフ法で定量する方法 について研究した。陚料の塩酸溶液を強塩基性陰イオン交換樹脂柱に通してカドミウムを吸着し, トリ ウムを素通りさせて分晟したのち希硝酸で溶離し，てれを直流または交流ポーラログラフ法で定量し た. 合成試料に上る添加害験，実際陚料の定量值の此較検討などから，本方法がトリウム中に含まれ る 0.01 数 ppm 程度のカドミウムの分截定量法として満足すべきものであるてとを見出した。本方 法は空試験值が小さく操作も容易で，定量誤差は $10 \%$ 以下，定量所要時間は $3 \sim 4$ 時間であった。 ま た，分離に液状陰イオン交換体を用いる方法も試み，定量所要時間を $1 \sim 2$ 時間に短縮することがで きた。
\end{abstract}

